\title{
Pelatihan Pembelajaran dan Penilaian Berbasis HOTS Bagi Guru SD Se- Kecamatan Mantrijeron Kota Yogyakarta
}

\author{
HOTS-Based Learning and Assessment Training for Elementary School Teachers in the District \\ of Mantrijeron, Yogyakarta City
}

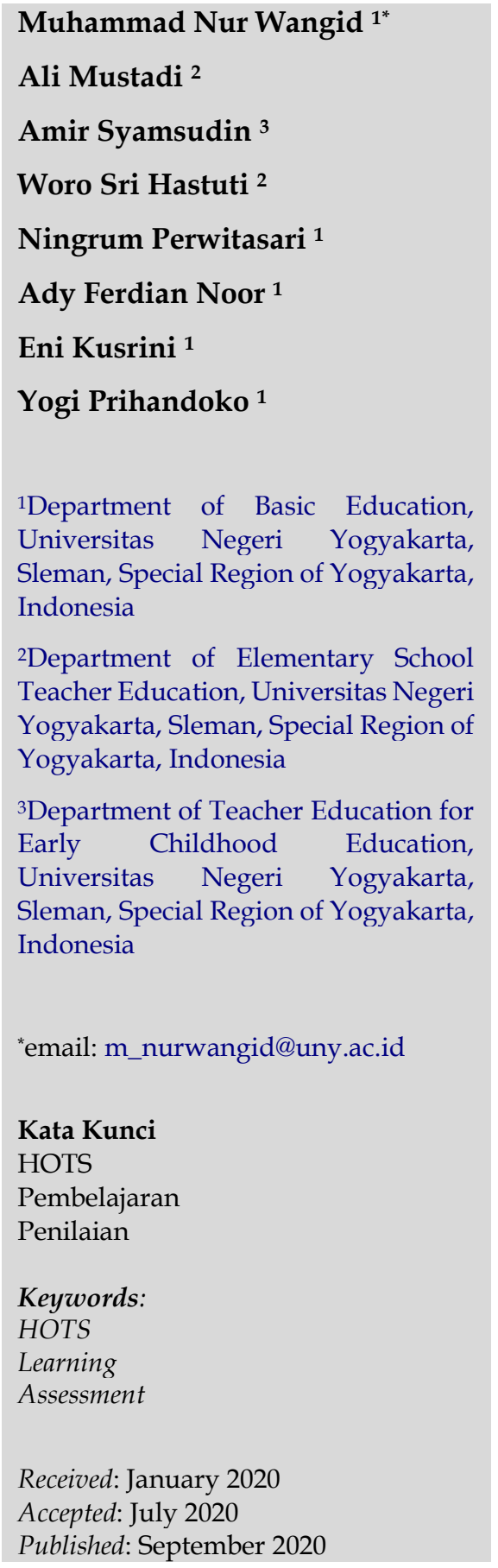

\begin{abstract}
Abstrak
Higher Order Thinking Skills (HOTS) merupakan cara yang mengedepankan nilai-nilai kritis dan kreatif sehingga dipandang mampu memberikan solusi dalam menghadapi perkembangan zaman. Metode yang digunakan deskriptif, untuk mendeskripsikan pembelajaran dan penilaian berbasis HOTS. Tujuan kegiatan ini yaitu meningkatkan kemampuan guru sekolah dasar (SD) dalam merancang perangkat pembelajaran berbasis HOTS yang terdiri dari RPP dan penilaian berbasis HOTS. Kegiatan ini dilatarbelakangi kesulitan yang dihadapi guru SD dalam implementasi kurikulum 2013 khususnya pada perancangan dan pelaksanaan pembelajaran berbasis HOTS, serta pengembangan penilaian berbasis HOTS. Oleh karena itu, kegiatan ini bertujuan agar guru menjadi profesional dalam mendidik peserta didik SD dalam mengembangkan kemampuan berpikir anak pada level yang lebih tinggi.
\end{abstract}

\begin{abstract}
Higher Order Thinking Skills (HOTS) is a way that puts forward critical and creative values so that it is seen as being able to provide solutions in facing the times. The method used is descriptive to describe HOTS-based learning and assessment. The purpose of this activity is to improve the ability of elementary school (SD) teachers in designing HOTS-based learning tools consisting of lesson plans and HOTS-based assessments. This activity is motivated by the skills faced by elementary school teachers in the implementation of the 2013 curriculum, especially in designing and implementing HOTS-based learning, as well as developing HOTS-based assessments. Therefore, this activity aims to make teachers become professionals in educating elementary students in developing children's thinking skills at a higher level.
\end{abstract}




\section{PENDAHULUAN}

Dalam mempersiapkan peserta didik di era milenia, dibutuhkan pembelajaran yang mampu mengembangkan berbagai aspek kompetensi yaitu afeksi, kognisi, dan psikomotorik. Kemampuankemampuan yang perlu dibekalkan kepada peserta didik antara lain adalah kemampuan berpikir kritis, kreatif, berkolaborasi, dan berkomunikasi yang sering disebut sebagai keterampilan abad XXI. Kemampuan berpikir kritis dan keratif merupakan bagian dari keterampilan Abad XXI yang berada pada ranah kognitif level tinggi. Bloom dalam taksonominya menyatakan level berpikir tingkat tinggi yaitu mulai dari remembering, understanding, applying, analyzing, evaluating, sampai dengan creating (Krathwohl, 2002). Kemampuan inilah yang diharapkan ditanamkan oleh guru pada peserta didik mulai jenjang sekolah dasar (SD) seperti halnya yang tertuang dalam Kurikulum 2013. Kemampuan berkolaborasi dan berkomunikasi juga penting dimiliki peserta didik pada abad XXI. Oleh karena itu, guru harus mampu membuat perencanaan, melaksanakan pembelajaran, dan melakukan penilaian yang mampu mengembangkan kemampuan-kemampuan tersebut. Permasalahan yang nampak adalah soal ujian nasional yang dikembangkan oleh pemerintah berbasis Higher Order Skills Thinking (HOTS), namun dalam pembelajaran di kelas, peserta didik mendapatkan pembelajaran yang belum dalam kategori HOTS (Baderan, 2018). Hal ini dipastikan menjadi salah satu penyebab kegagalan peserta didik dalam menghadapi ujian nasional. Fakta lain terkait hal ini adalah temuan dari hasil penelitian bahwa 91,43\% guru menyatakan memahami konsep dari HOTS dan 8,57\% responden belum memahami. Sebesar $85,71 \%$ responden berpendapat HOTS bisa diajarkan pada tingkat sekolah dasar, 11,43\% berpendapat HOTS belum bisa diajarkan dan $2,86 \%$ responden menjawab tidak tahu. Sebanyak
82,86\% responden sudah menerapkan HOTS pada kegiatan pembelajaran dan $17,14 \%$ responden belum menerapkan. Namun, sebesar 79\% responden kesulitan dalam merancang dan menerapkan evaluasi berbasiskan HOTS, 59\% kesulitan dalam penyampaian materi pembelajaran, $45 \%$ kesulitan dalam merancang media pembelajaran, $38 \%$ kesulitan dalam merancang perangkat pembelajaran dan sebesar $31 \%$ kesulitan dalam proses penyusunan bahan ajar (Rapih \& Sutaryadi, 2018). Guru menyatakan memahami HOTS namun masih mengalami kesulitan dalam implementasinya.

Survei yang dilakukan terhadap peserta didik kelas IV SD Muhammadiyah 2 Kauman Surakarta menghasilkan data bahwa kemampuan berpikir kritis peserta didik dalam pembelajaran IPA masih rendah, yaitu sekitar $10 \%$ peserta didik yang aktif dalam kegiatan pembelajaran dan $90 \%$ peserta didik lainnya belum aktif dalam kegiatan pembelajaran (Setiawati, 2013). Guru di kelas masih berperan sangat dominan sebagai pusat pembelajar dan peserta didik hanya dibiarkan duduk, mendengar dan mencatat.

Beberapa SD di Mantrijeron Kota Yogyakarta, berdasarkan wawancara kebutuhan guru untuk meningkatkan kualitas pembelajarannya, kebanyakan guru mengalami kesulitan dalam mengimplementasikan pembelajaran berbasis HOTS, padahal Kurikulum 2013 mengarahkan guru untuk melakukan pembelajaran seperti ini. Peserta didik mengalami ketidaksiapan ketika mengerjakan soal-soal berbasis HOTS. Arahan pemerintah untuk melaksanakan pendidikan sesuai standar nasional pendidikan juga sulit dapat terwujud dengan pembelajaran yang masih konvensioanal.

Dengan demikian dapat dinyatakan bahwa persoalan pengembangan pembelajaran berbasis HOTS terjadi pada banyak guru di berbagai wilayah. Pemerintah telah 
mengembangkan panduan pengembangan pembelajaran berbasis HOTS, namun sosialisasi dan pelatihan masih dalam proses padahal guru sangat membutuhkan pelatihan ini untuk segera direalisasikan. Oleh karena itu, pelatihan pengembangan pembelajaran berorientasi HOTS perlu untuk segera dilaksanakan.

Perkembangan ilmu pengetahuan dan teknologi menuntut adaptasi yang baik dalam dunia pendidikan. Dunia pendidikan sebagai sarana dalam pengembangan ilmu pengetahuan dan teknologi harus terus berkembang dan berproses seuai dengan perkembangan zaman. Standar-standar dalam output maupun outcome pendidikan juga terus mengalami peningkatan seiring dengan perubahan dan tuntutan zaman. Salah satu isu terkini dalam dunia pendidikan modern adalah pembentukan HOTS bagi peserta didik. Selain itu, HOTS merupakan suatu tingkat berfikir yang menekankan pada penerapan pengetahuan yang telah diterima, penalaran refleksi, pemecahan masalah, pengambilan keputusan, dan selanjutnya merumuskan pada suatu hal yang baru (Sulaiman et al., 2017; Widodo \& Kadarwati, 2013; Brookhart, 2010; King et al., 2006). HOTS merupakan suatu keahlian dalam berfikir yang mencakup hal-hal di atas. Peserta didik yang mencapai level HOTS akan mampu menerapkan pengetahuan secara kreatif dan kritis sehingga suatu pengetahuan akan terus di proses dan akhirnya akan menghasilkan suatu pemecahan masalah.

Konsep HOTS berasal dari teori taksonomi Bloom (1956) dalam ranah kognitif yang melibatkan perkembangan keterampilan intelektual dan secara bertahap berkembangan dari cara berfikir konkret ke abstrak (Rapih \& Sutaryadi, 2018; Pappas et al., 2013). Dalam HOTS, peserta didik diharuskan menguasai suatu pengetahuan dalam level menganalisis (Analyze), mengevaluasi (Evaluated) dan mencipta (Created). Sehingga daya nalar dan daya kritis berfikir peserta didik sangat dibutuhkan dalam HOTS. Keterampilanketerampilan tersebut yang menjadi inti dalam HOTS merupakan modal utama peserta didik dalam menjalani kehidupan. Konsep HOTS telah mengalami beberapa pengembangan dan faktor-faktor yang berkontribusi terhadap pengembangan HOTS pada peserta didik telah menjadi bahan kajian selama beberapa tahun terakhir (Noble \& Powell, 1995; Nagappan, 2001; Marshall \& Horton, 2011; Magno, 2011; Fischer et al., 2011; Uzuntiryaki-Kondakci \& Capa-Aydin, 2013). Berdasarkan beberapa kajian dan penelitian, faktorfaktor yang mempengaruhi HOTS antara lain: lingkungan kelas, karakteristik keluarga, karakteristik psikologis, dan kecerdasan (Horan, 2007; Silvia, 2008; Pannells \& Claxton, 2008; Lim \& Smith, 2008; Chini et al., 2009; Pascarella et al., 2013; Fearon et al., 2013; Lather et al., 2014).

Urgensi dari HOTS menjadi semakin kuat ketika The Partnership 21st century skills merumuskan kerangka kerja pembelajaran abad 21. Dalam kerangka kerja tersebut, konten akademik yang berupa 3rs (Writing, reading, dan aritmethics) dan 4cs (berfikir kritis, pemecahan masalah, kolaborasi dan kreativitas dan inovasi) merupakan hal sangat penting dalam kegiatan pembelajaran di abad 21. Jika merujuk dalam kerangka kerja tersebut, maka HOTS merupakan jawaban dalam menjawab tantangan dalam pembelajaran abad 21. Disamping itu, dengan HOTS peserta didik akan terbiasa berpikir kritis dan kreatif baik dalam pengambilan keputusan dan pemecahan masalah yang berkaitan dengan menganalisis, mengevaluasi dan mencipta (Anderson \& Krathwohl, 2001).

Untuk mencapai tujuan dalam pembentukan HOTS pada peserta didik, maka diperlukan suatu proses pembelajaran yang harus mengakomodir perkembangan HOTS. Pembelajaran yang aktif, berpusat pada peserta didik, pembentukan rasa ingin tahu (keinginan bertanya) dan penilaian yang berdasar 
pada HOTS merupakan salah satu cara untuk pencapaian peserta didik ke HOTS (Boaler \& Staples, 2008; Franco et al., 2007). Penekanan utama dalam kegiatan pembelajaran guna membentuk HOTS adalah pada proses pembelajaran Student Center Learning (SCL). Peserta didik yang mengikuti kegiatan pembelajaran dengan model SCL dan mendapatkan tantangantantangan selama peserta didik belajar terbukti menunjukkan pertumbuhan otan 25\% lebih cepat dibandingkan dengan yang tidak mendapatkan perlakuan tersebut (Conklin \& Manfro, 2012). Pembelajaran untuk mencapai HOTS memerlukan sinergi yang kuat antara seluruh pelaku pendidikan. Dimulai dari kurikulum sebagai fundamen dasar kegiatan pendidikan harus diterapkan secara komprehensif dan kontekstual. Kurikulum beserta komponen-komponen dibawahnya termasuk pelaku utama yaitu guru dituntut untuk terusberupaya mengembangkan keahlian dalam proses pembelajaran agar peserta didik mencapai tingkatan HOTS. Di Indonesia sendiri, diterapkannya kurikulum 2013 sebenarnya merupakan fondasi kuat guna mencapai HOTS pada peserta didik. Dari sisi teknis pembelajaran di kelas, untuk mencapai HOTS dapat dilakukan minimal dengan beberapa cara salah satunya dengan memberikan beberapa motivasi yang dapat dilakukan guru di kelas (Conklin \& Manfro, 2012). Motivasimotivasi tersebut dapat berupa membuka dan mengakhiri pelajaran dengan pertanyaan- pertanyaan yang mengarah pada keterampilan berpikir tingkat tinggi, menempatkan aktivitas brainstorming pada pertengahan pelajaran untuk mendorong peserta didik menemukan ide dan berpikir kreatif, memberikan tugas berbasis open ended sebagai pekerjaan rumah untuk mengetahui kreativitas dan pemahaman mereka terhadap pelajaran yang sudah dipelajari (Hidayati, 2017).
Penerapan kurikulum 2013 pada tingkat dasar sampai menengah merupakan upaya dalam meningkatkan kualitas output dan outcome pendidikan di Indonesia. Kurikulum 2013 sebagai sarana dalam pencapaian HOTS sejak tingkatan Sekolah Dasar (SD) merupakan upaya yang sangat bagus dalam meningkatkan kualitas berfikir peserta didik sedini mungkin. Melatih peserta didik agar pada tingkatan HOTSjuga akan lebih baikjika dimulai sejak bangku sekolah dasar. Berdasarkan teori perkembangan, peserta didik sekolah dasar sudah mampu untuk mulai dikenalkan dengan model-model pembelajaran yang merangsang untuk mencapai HOTS. Dengan modal fundamen dasar pendidikan yang sudah mulai dirintis berupa kurikulum 2013, pelaksanaan pembelajaran untuk mewujudkan HOTS pada peserta didik SD sebenarnya sudah berada pada jalur yang benar. Namun, beberapa hambatan sampai saat ini masih banyak dijumpai baik dari sisi penerapan kurikulum maupun dari sisi pembelajaran dalam perpektif HOTS. Lemahnya implementasi kurikulum 2013 yang disebabkan berbagai faktor menjadikan hasil produk dari kurikulum tersebut sampai saat ini belum optimal.

Penelitian-penelitian mengenai problematika implementasi kurikulum 2013 secara garis besar mendapatkan hasil yang sejalan. Berdasarkan hasil penelitian, permasalahan implementasi kurikulum 2013 ada pada 3 ranah yaitu ranah pemerintah, ranah institusi (sekolah) dan ranah guru. Pada ranah guru kendalam implementasi kurikulum 2013 secara garis besar meliputi kurang efektifnya pelatihan guru, pemahaman tentang konsep dan prosedur penilaian, pembuatan media pembelajaran, pemahaman guru, pemaduan antar muatan pelajaran dalam pembelajaran tematik, dan penguasan teknologi informasi (Ahmad, 2014; Krissandi \& Rusmawan, 2015; Wahyudi \& Chamdani, 2017). 
Peraturan Pemerintah Nomor 32 Tahun 2013 tentang Perubahan atas Peraturan Pemerintah Nomor 19 Tahun 2005 tentang Standar Nasional Pendidikan merupakan kunci untuk mencapai tingkatan HOTS menyatakan bahwa guru mempunyai peran yang sangat penting dalam upaya menjadikan peserta didik mampu berada pada level HOTS. Permasalahan utama yaitu guru belum mengetahui bagaimana cara mengajarkan pembelajaran yang menuju HOTS (Hidayati, 2017). Tujuan dari penelitian ini yaitu untuk mengetahui dan memberikan gambaran tentang pemahaman guru kelas Sekolah Dasar terhadap HOTS. Selain itu, penelitian ini juga mencoba untuk memberikan gambaran tentang pembelajaran yang dilakukan oleh guru kelas SD guna mencapai tingkatan HOTS dan dampak terhadap motivasi peserta didik sekolah dasar. Hasil penelitian ini diharapkan akan menjadi bahan masukan dalam perumusan kebijakan terutama dalam pengembangan kompetensi guru.

\section{METODOLOGI}

Penelitian ini menggunakan penelitian deskriptif. Setyosari (2015) mengemukakan penelitian ini berusaha untuk mendeskripsikan pelaksanaan pembelajaran dan penilaian berbasis HOTS yang dilakukan oleh guru sekolah dasar melalui pemahaman dan pembuatan media literasi kelas awal sehingga mampu menjadi salah satu kompetensi yang diharapkan meningkatkan level peserta didik dalam belajar dan berpikir. Data dikumpulkan melalui observasi, angket, dan pre-test dan post-test. Guru juga diharuskan membuat unjuk kerja dan hasil karya.

Kegiatan pelatihan pembelajaran dan penilaian berbasis HOTS bagi guru sekolah dasar se-Kecamatan Mantrijeron Kota Yogyakarta diselenggarakan di SD Pedagogia. Lokasi dipilih berdasarkan beberapa pertimbangan, yaitu kemudahan dan keterjangkauan bagi para peserta pelatihan, serta lokasi ini mudah diakses dari arah manapun di Kecamatan Mantrijeron, Kota Yogyakarta.

\section{HASIL DAN PEMBAHASAN}

Kegiatan yang dilaksanakan melalui pelatihan dengan metode In House Training and Workshop. Pelatihan yang diberikan terdiri atas dua tahap. Pada tahap pertama, guru-guru SD se-Kecamatan Mantrijeron Kota Yogyakarta tersebut diberikan pelatihan perancangan pembelajaran HOTS dan penyusunan penilaian berbasis HOTS yang terdiri atas:

1. Pelatihan perancangan pembelajaran di SD berbasis HOTS.

2. Pelatihan penyusunan penilaian di SD yang berbasis HOTS.

3. Pelatihan implementasi pembelajaran di SD berbasis HOTS dan penerapan penilaian di SD yang berbasis HOTS.

Selanjutnya guru diberikan tugas untuk merancang pembelajaran SD berbasis HOTS dan menyusun penilaian pembelajaran SD berbasis HOTS serta diberi waktu selama satu minggu.

Pada tahap kedua, para peserta mengumpulkan dan mempresentasikan hasil rancangan pembelajaran SD berbasis HOTS dan penilaian pembelajaran SD berbasis HOTS. Dalam kegiatan presentasi itu diberikan masukan dan saran untuk rancangan pembelajaran SD berbasis HOTS dan penilaian pembelajaran SD berbasis HOTS. Kegiatan pelatihan tersebut dilaksanakan secara sistematis dan terkait satu sama lain sehingga guru mampu membuat rancangan pembelajaran SD berbasis HOTS dan penilaian pembelajaran SD berbasis HOTS yang berkualitas.

Langkah-langkah rinci kegiatan pelatihan tahap pertama dan kedua sedikit berbeda. Pada tahap pertama, 
kegiatan pelatihan ini dirancang selama satu hari penuh dengan susunan kegiatan sebagai berikut.

1. Pada sesi pertama diisi dengan pemaparan materi tentang karakteristik pembelajaran berbasis HOTS di SD, rancangan pembelajaran berbasis HOTS di SD, implementasi pembelajaran berbasis HOTS di SD, dan penilaian pembelajaran berbasis HOTS diSD.

2. Pada sesi kedua diisi dengan kegiatan praktik merancang pembelajaran dan penilaian berbasis HOTS di SD. Para peserta diminta untuk praktik langsung dalam merancang pembelajaran dan penilaian berbasis HOTS diSD.

3. Pada sesi ketiga diisi dengan kegiatan praktik implementasi pembelajaran dan penilaian berbasis HOTS di SD yang dibantu oleh mahasiswa Pendidikan Dasar S3.

Pada tahap kedua, kegiatan pelatihan ini dirancang selama satu hari dengan acara sebagai berikut:

1. Pada sesi pertama para peserta mempresentasikan hasil rancangan pembelajaran dan penilaian berbasis HOTS di SD yang telah dibuat buat selama satu minggu. Terdapat beberapa masukkan baik yang berasal dari dosen tim pengabdi maupun dari rekan sejawat peserta.

2. Pada sesi kedua para peserta melakukan revisi rancangan pembelajaran dan penilaian berbasis HOTS di SD berdasarkan masukkan dan saran yang telah diberikan, kemudian mengumpulkan rancangan pembelajaran dan penilaian berbasis HOTS di SD tersebut kepada panitia. Setelah itu kegiatan ditutup secara resmi dan ada pembagian sertifikat untuk para peserta.

Pemahaman Guru Mengenai Pembelajaran dan Penilaian Berbasis HOTS

Hasil pengumpulan data melalui angket menunjukkan banyaknya kendala yang dihadapi guru manakala guru merancang perangkat pembelajaran berbasis HOTS.
Kendala yang paling sering ditemui dalam mengajarkan HOTS adalah kurangnya pemahaman guru dan peserta didik dalam menerapkan proses pembelajaran HOTS secara taksonomi Bloom. Guru belum paham bagaimana praktek pembelajran berbasis HOTS. Secara kognitif, peserta didik belum memahami bagaimana prosedur belajar menggunakan HOTS. Kendala ini diakui oleh sedikitnya 47,6\% peserta pelatihan. Akibatnya, pemahaman guru secara kognitif masih parsial mengenai implementasi HOTS dalam pembelajaran, guru sebatas mengetahui HOTS adalah pembelajaran menggunakan tingkat berpikir tinggi, tingkat berpikir seperti apa yang dimaksud, bagaimana implementasinya dalam pembelajaran dan belum mencapai tingkatan indikator lain taksonomi Bloom tentang kognitif.

Pemahaman guru yang parsial hanya cenderung pada aspek kognitif membuat implementasi HOTS dalam pembelajaran kurang tepat. Begitupun dalam hal penilaian berbasis HOTS hanya sampai pada aspek kognitif kurang menyentuh aspek afektif dan psikomotor. Peserta didik hanya diberikan soal-soal yang sebatas sulit, belum benar-benar soal latihan berbasisi HOTS. Bahkan soal yang diberikan kadang kurang masuk akal, hanya berdasar asalkan sulit bagi peserta didik. Misalnya saja sepotong roti dibagi untuk delapan anak, anak melogika mengapa sepotong roti kecil harus diiris lagi menjadi delapan? Bagaimana memakan roti kecil yang masih harus dipotong menjadi delapan lagi?

Permasalahan lain yang menyebabkan implementasi HOTS kurang tepat yaitu rendahnya motivasi belajar peserta didik menggunakan HOTS semata karena pendekatan dan metode yang diterapkan belum tepat. Hal tersebut menyebabkan peserta didik bingung harus menjawab pertanyaan guru maupun menjalani pembelajaran. Namun, rendahnya motivasi peserta 
didik dalam pembelajaran HOTS hanya ditemui oleh $31 \%$ peserta pelatihan. Kendala-kendala diatas dianggap kendala yang paling urgent karena sebagian pesera pelatihan (para guru) berasumsi bahwa selama praktik di lapangan mengenai pembelajaran berbasis HOTS kurang dipahami benar, tujuan pembelajarannya berdasarkan konsep dan taksonomi Bloom kurang dapat tercapai.

Pelaksanaan Pelatihan Pembuatan Media Literasi untuk Kelas Awal

Pelatihan dilakukan melalui dua tahapan, tahap pertama yaitu workshop untuk penyampaian materi terkait pembuatan perangkat berupa pembelajaran berupa pembelajaran dan penilaian berbasis HOTS dan dilanjutkan praktik pembuatan perangkat pembelajaran berbasis HOTS oleh peserta (unjuk kerja dan Hasil karya). Materi yang disampaikan berkaitan dengan teoriteori yang dijadikan landasan dalam pembelajaran dan penilaian berbasis HOTS hingga cara penyusunan perangkatnya. Setelah peserta memahami beberapa materi tersebut, selanjutnya peserta diberikan kesempatan untuk berlatih membuat salah satu di antara RPP atau penilaian pembelajaran berbasis HOTS yang selanjutnya akan dipresentasikan kepada peserta lainnya. Proses pembuatan perangkat pembelajaran ini dilakukan selama satu minggu.

Perangkat pembelajaran yang dibuat disesuaikan dengan teori-teori yang telah dipaparkan pada tahapan pertama. Dasar pembuatan perangkat pembelajaran ini selanjutnya juga menjadi tugas yang harus disampaikan peserta kepada peserta lainnya, sehingga masing-masing peserta memiliki pemahaman terhadap konsep teori dalam masing-masing media yang dibuat. Perangkat pembelajaran yang telah dipresentasikan selanjutnya diberikan saran untuk perbaikan berikutnya. Dokumentasi kegiatan pelatihan disajikan pada Gambar 1 dan 2

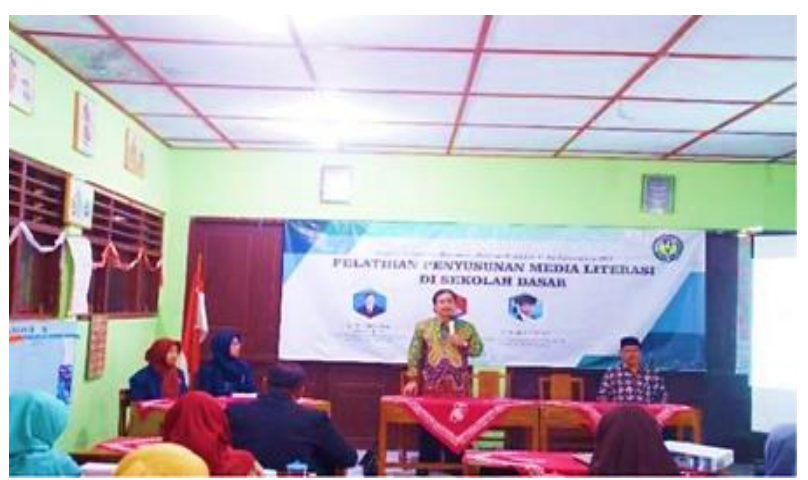

Gambar 1. Penyampaian Materi Pembuatan Perangkat Pembelajaran Berbasis HOTS

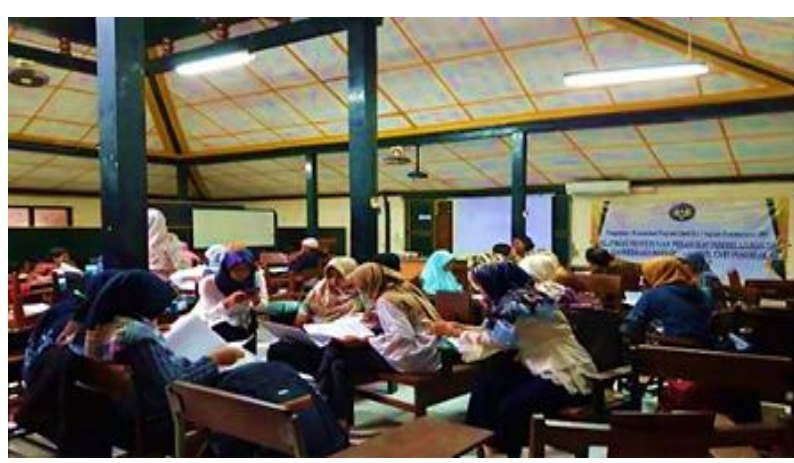

Gambar 2. Proses Pembuatan Perangkat Pembelajaran Berbasis HOTS

Evaluasi Pelaksanaan Pelatihan Berdasarkan Hasil Pre-test dan Post-test Peserta

Hasil evaluasi pelatihan pembuatan perangkat pembelajaran berbasis HOTS, partisipan mengalami beberapa peningkatan. Peningkatan yang dimaksud berupa peningkatan pengetahuan, keterampilan, dan produk. Dari hasil pre-test dan post-test, contohnya, yang menunjukkan skor mean pre-test sebesar 42,52 sebelum dilakukan pelatihan. Skor tersebut mengalami peningkatan menjadi 62,63 setelah dilakukan pelatihan pembuatan media. Berdasarkan data tersebut kemudian dibuat tabel klasifikasi ketercapaian pelatihan pembuatan media literasi mengunakan nilai Gain score seperti disajikan pada Tabel I.

Tabel I. Nilai Gain score

\begin{tabular}{cc}
\hline Nilai N-Gain & Kategori \\
\hline $\mathrm{g}>0,7$ & Tinggi \\
$0,3 \leq \mathrm{g} \leq 0,7$ & Sedang \\
$\mathrm{g}<0,3$ & Rendah \\
\hline
\end{tabular}


Hasil perhitungan nilai gain skor dari hasil pre-test dan post-test diperoleh hasil nilai Gain score sebesar 1,99. Berdasarkan tabel diatas, hasil pelatihan pembuatan perangkat pembelajaran berbasis HOTS dalam kategori tinggi. Hal tersebut dapat disebabkan karena peserta sudah mendapat materi pengenalan mengenai HOTS beberapa kali, namun belum difokuskan pada bagaimana metode dan pendekatan pembelajaran yang bisa diterapkan HOTS, bagaimana penilaian HOTS yang nyata, serta praktek langsung membuat perangkat pembelajaran berbasis HOTS. Untuk itu masih dibutuhkan pelatihan lanjutan pembuatan perangkat pembelajaran berbasis HOTS untuk guru-guru sekolah dasar di UPT Mantrijeron.

\section{KESIMPULAN}

Kegiatan PPM ini mampu memberikan kontribusi positif bagi guru-guru tentang penyusunan perangkat pembelajaran dan penilaian berbasis HOTS. Kontribusi positif yang nampak pada guru-guru setelah mengikuti kegiatan ini yaitu guru-guru mampu mengembangkan perangkat pembelajaran dan penilaian HOTS pada beberapa mata pelajaran misalnya IPA dan PKn. Pelatihan ini perlu terus dilaksanakan dan dikembangkan pada materi pendalaman penilaian HOTS pada semua mata pelajaran sesuai dengan pembelajaran abad 21 dan era Industri 4.0 dan komunitas 5.0.

\section{UCAPAN TERIMA KASIH}

Terima kasih diucapkan kepada Direktur Pascasarjana Universitas Negeri Yogyakarta beserta jajarannya dan Ibu Guru SD Se-Kecamatan Mantrijeron Kota Yogyakarta.

\section{REFERENSI}

Ahmad, S. 2014. Problematika Kurikulum 2013 Dan Kepemimpinan Instruksional Kepala Sekolah. Pencerahan. 8(2):98-108. https://doi.org/10.13170/jp.8.2.2158

Anderson, L.W., Krathwohl, D.R. 2001. A Taxonomy for Learning, Teaching, and Assessing: A Revision of Bloom's Taxonomy of Educational Objectives. New York: Addison-Wesley Longman Ltd.

Baderan, J.K. 2018. Pengembangan Soal High Order Thinking (HOT) Melalui Pembelajaran Berbasis Masalah Untuk Melatih Keterampilan Berpikir Kritis Peserta Didik Kelas VISD. Pedagogika. 9(2):152-178.

Bloom, B.S. 1956. Taxonomy of Educational Objectives, Handbook 1: Cognitive Domain. New York: Addison-Wesley Longman Ltd.

Boaler, J., Staples, M. 2008. Creating Mathematical Futures through an Equitable Teaching Approach: The Case of Railside School. Teacher College Record. 110(3):608-645.

Brookhart, S.M. 2010. How to Assess Higher-Order Thinking Skills in Your Classroom. Alexandria: ASCD.

Chini, J.J., Carmichael, A., Rebello, N.S., Puntambekar, S. 2009. Does the Teaching/Learning Interview Provide an Accurate Snapshot of Classroom Learning? Proceedings of the 2009 Physics Education Research Conference, AIP Publications, July 29-30. 1179:113-116.

Conklin, W., Manfro, J. 2012. Higher order thinking skills to develop 21 ${ }^{\text {st }}$ century learners. Huntington: Shell Education Publishing, Inc.

Fearon, D.D., Copeland, D., Saxon, T.F. 2013. The relationship between parenting styles and creativity in a sample of Jamaican children. Creativity Research Journal. 25(1):119-128. https:/ / doi.org/10.1080/10400419.2013.75228 7

Fischer, C., Bol, L., Pribesh, S. 2011. An Investigation of Higher-Order Thinking Skills in Smaller Learning Community Social Studies Classrooms. American Secondary Education. 39(2):5-26.

Franco, C., Sztajn, P., Ortigão, M.I.R. 2007. Mathematics Teachers, Reform, and Equity: Results from 
the Brazilian National Assessment. Journal for Research in Mathematics Education. 38(4):393419. https://doi.org/10.2307/30034880

Hidayati, A.U. 2017. Melatih Keterampilan Berpikir Tingkat Tinggi Dalam Pembelajaran Matematika Pada Siswa Sekolah Dasar. Terampil : Jurnal Pendidikan dan Pembelajaran Dasar. $\quad$ 4(2):143-156. https://doi.org/10.24042/terampil.v4i2.2222

Horan, R. 2007. The Relationship Between Creativity and Intelligence: A Combined Yogic-Scientific Approach. Creativity Research Journal. 19(23):179-202.

https://doi.org/10.1080/10400410701397230

King, F.J., Goodson, L., Rohani, F. 2006. Higher Order Thinking Skills: Definition, Teaching Strategies, and Assesment. London: Center for Advancement of Learning and Assessment.

Krathwohl, D.R. 2002. A Revision of Bloom's Taxonomy: An Overview. Theory Into Practice. 41(4):212218. https://doi.org/10.1207/s15430421tip4104_2

Krissandi, A.D.S., Rusmawan, R. 2015. Kendala Guru Sekolah Dasar Dalam Implementasi Kurikulum 2013. Cakrawala Pendidikan. 34(3):457-467.

https://doi.org/10.21831/cp.v3i3.7409

Lather, A.S., Jain, S., Shukla, A.D. 2014. Student's Creativity in Relation to Locus of Control: a Study of Mysore University, India. The International Journal of Indian Psychology. 2(1):146-165.

Lim, S., Smith, J. 2008. The Structural Relationships of Parenting Style, Creative Personality, and Loneliness. Creativity Research Journal. 20(4):412-419.

https://doi.org/10.1080/10400410802391868

Magno, C. 2011. Assessing the Relationship of Scientific Thinking, Self-regulation in Research, and Creativity in a Measurement Model. International Journalof Research and Review. 6(1):22-47.

Marshall, J.C., Horton, R.M. 2011. The Relationship of Teacher-Facilitated, Inquiry-Based Instruction to Student Higher-Order Thinking. School Science and Mathematics. 111(3):93-101.
Nagappan, R. 2001. The Teaching of Higher Order Thinking Skills in Malaysia. Journal of Southeast Asian Education. 2(1):42-65.

Noble, J., Powell, D.A. 1995. Factors Influencing Differential Achievemen of Higher-order Thinking Skills, as Measured by PLAN. ACT Research Report Series. 95:4.

Pannells, T.C., Claxton, A.F. 2008. Happiness, creative ideation, and locus of control. Creativity Research Journal. 20(1):67-71. https://doi.org/10.1080/10400410701842029

Pappas, E., Pierrakos, O., Nagel, R. 2013. Using Bloom's Taxonomy to teach sustainability in multiple contexts. Journal of Cleaner Production. 48:54-64. https://doi.org/10.1016/j.jclepro.2012.09.039

Pascarella, E.T., Wang, J.S., Trolian, T.L., Blaich, C. 2013. How the instructional and learning environments of liberal arts colleges enhance cognitive development. Higher Education. 66:569-583. https://doi.org/10.1007/s10734013-9622-z

Rapih, S., Sutaryadi, S. 2018. Perpektif guru sekolah dasar terhadap Higher Order Tinking Skills (HOTS): pemahaman, penerapan dan hambatan. Premiere Educandum : Jurnal Pendidikan Dasar dan Pembelajaran. 8(1):78-87. http://doi.org/10.25273/pe.v8i1.2560

Setiawati, G.A.D. 2013. Pemanfaatan Subak Dalam Pembelajaran IPA (Upaya Mewujudkan Pembelajaran IPA Yang Mendukung Implementasi Kurikulum 2013). Seminar Nasional FMIPA UNDIKSHA III Tahun 2013. Denpasar: Universitas Pendidikan Ganesha.

Setyosari, P. 2015. Metode Penelitian: Pendidikan dan Pengembangan. Jakarta: Prenada Media Group.

Silvia, P.J. 2008. Creativity and Intelligence Revisited: A Latent Variable Analysis of Wallach and Kogan (1965). Creativity Research Journal. 20(1):34-39. https://doi.org/10.1080/10400410701841807

Sulaiman, T., Muniyan, V., Madhvan, D., Hasan, R., Rahim, S.S.A. 2017. Implementation of Higher Order Thinking Skills in Teaching Of Science: A Case Study in Malaysia. International Research Journal of Education and Sciences. 1(1):13. 
Uzuntiryaki-Kondakci, E., Capa-Aydin, Y. 2013. Predicting Critical Thinking Skills of University Students through Metacognitive Self-Regulation Skills and Chemistry SelfEfficacy. Educational Sciences: Theory and Practice. 13(1):666-670.

Wahyudi, W., Chamdani, M. 2018. Implementasi Kurikulum 2013 Di Sekolah Dasar Masalah Dan Solusinya (Studi Kasus Di Kabupaten Kebumen). Dwija Cendekia: Jurnal Riset Pedagogik. 1(1):92-108. https://doi.org/10.20961/jdc.v1i1.14492

Widodo, T., Kadarwati, S. 2013. Higher Order Thinking Berbasis Pemecahan Masalah Untuk Meningkatkan Hasil Belajar Berorientasi Pembentukan Karakter Siswa. Cakrawala Pendidikan. 23(1):161-171. https://doi.org/10.21831/cp.v5i1.1269 